\title{
«ЛОНО ТРАДИЦИИ» \\ (РАЗМЫШЛЯЯ НАД ОБРАЗОМ-ПОНЯТИЕМ)
}

\section{Ю. Г. Писаренко}

Жизнь человечества или даже вообще жизнь на Земле могла бы быть признана самой главной традицией или «традицией традиций». Такую мысль позволительно высказать именно потому, что значение слова «традиция» (от лат. traditio - передача) наиболее естественно воплощается в бесконечной эстафете поколений. Можно было бы возразить против такого мнения, ведь традиция представляется как нечто сознательно установленное, а жизнь зародилась задолго до возникновения человеческого сознания. Однако, во-первых, в восприятии традиции самими людьми ее ценность определяется ее существованием «с незапамятных времен», а во-вторых, нельзя исключить, что в основе жизни лежит сознательный, божественный импульс. Поэтому, жизнь, как и традиция - это то, что длится, передается, сберегается и чье авторство доподлинно не известно.

Говоря о жизни, как о, своего рода, традиции, мы не можем в этом смысле приравнять жизнь к истории. Последняя, скорее, противостоит жизни как «традиции», поскольку, главным образом, является чередой войн, ломкой традиций, испытывающей на человеке все новые и новые средства уничтожения. И жизни приходится преодолевать историю как препятствие, подтверждая свою устойчивость в качестве традиции.

Передача традиций в биологии, на генетическом уровне, могла бы рассматриваться как модель любой традиции ${ }^{1}$, в которой устойчивое

\footnotetext{
${ }^{1}$ Мысль о «биологичности» традиции встречается и у Я.Пеликана, который отмечает, что в отличие от наших ДНК, традиция, которую мы осознали, ста-
} 
сохранение тех или иных идеологических форм, в конечном итоге, служит задаче физического выживания коллектива, и традиция, таким образом, выступает проявлением идеи так называемой «социовитальности» ${ }^{2}$. Возможно, именно поэтому наиболее долговечны традиции брака и семьи, поскольку в первую очередь именно они стоят на страже продолжения жизни - биологической преемственности поколений. Например, тот или иной свадебный обряд, утрачивая непосредственную опору в породившем его социальном строе, в изменившихся условиях жизни сохраняет роль общественной легитимации брака.

Приведем одну, на наш взгляд, яркую иллюстрацию такого длительного сохранения традиции в свадебном обряде. У белорусов Ржевского уезда бывшей Тверской губернии (середина XIX в.) бытовал следующий обычай. Перед поездкой жениха к невесте его вначале одевали в подобающий для свадьбы наряд. Затем он со своей дружиной выходил на двор. Приносили самых больших размеров сковороду, на нее обеими ногами ставили жениха. Затем вся его дружина, не менее 6-8 человек, становилась вокруг сковороды, и каждый ставил на сковороду свою правую ногу. В таком положении все целовали икону, и старший дружко говорил: «Ну, цалуйте Божие милосердие, щоб стаятсь друг за друга, брат за брата, за единую кровь капли», то есть давалась присяга ${ }^{3}$. По справедливому заключению Н. М. Никольского, «присяга эта имела смысл только в родоплеменную эпоху, когда молодец со своей „радзінай“ отправлялся добывать себе жену мечом и стрелой. Тогда присяга приносилась, конечно, не христианскому богу, а тому богу, символом которого являлась сковорода» ${ }^{4}$. Автор прихо-

вит нас перед выбором между ее воспроизведением и отбрасыванием (Пеликан Я. Виправдання традиції. - K., 2010. - С. 79). Однако, на наш взгляд, современная возможность такого выбора, вышедшая за рамки некритического восприятия традиции, говорит уже о смерти традиции в первоначальном смысле, ведь традиция - это не «товар на полке супермаркета». Но раз уж мы живем в современном, а не традиционном обществе, то мы целиком поддерживаем следующее мнение Я. Пеликана: «Зрелость в отношениях с родителями предполагает выход за пределы и веры в их всемогущество, и неуважения к их слабостям - в направлении осознания и благодарности за их решающее участие в процессе, к котрому должны присоединиться и мы, как их свободные наследники. Таким должно быть и отношение к нашему интеллектуальному и духовному наследию - традиции» ( Там же).

2 Писаренко Ю. Г. Соціовітальність та Едіпів комплекс не за Фрейдом // Мультиверсум. Філософський альманах. - К., 2009. - Вип. 88. - С. 87-88.

${ }^{3}$ Разумихин C. Село Бобровки и его окружный околоток. Тверской губернии Ржевского уезда // Этнографический сборник. - СПб., 1853. - Вып. 1. - С. 255.

${ }^{4}$ Николъский Н. М. Происхождение и история белорусской свадебной обрядности. - Мн., 1958. - С. 64. 
дил к выводу, что сковорода, как в других обрядах кочерга и ухват, считались символом духа предка, живущего в печи или на очаге. Таким образом, клятва произносилась перед богом-предком и даже в соприкосновении с ним - с его символом, сковородой ${ }^{5}$.

Подобный обряд присяги, причем в случае аналогичного добывания невесты, находим у греческого писателя II-го в. н. э. Лукиана Самосатского в произведении «Токсарид, или Дружба», где приводится сопоставление греческих и скифских традиций, касающихся дружбы. Некий скиф, Арсаком посватался к дочери боспорского царя, Мазае, но был отвергнут из-за своей бедности, и высмеян на пиру. Мазая же была отдана замуж за богатого правителя махлийцев Адирмака. Оскорбленный скиф, вернувшись на родину, рассказал о случившемся двум своим друзьям, Лонхату и Макенту, которые восприняли его оскорбление как свое. Приняв решение отомстить за обиду и вернуть побратиму его любимую, они, для сбора необходимых сил, советуют Арсакому «сесть на шкуру быка». Обычай этот состоял в следующем: «Если кто-нибудь, желая себя защитить от обиды, увидит, что у него не хватает достаточно сил, то приносит в жертву быка и, нарезав мясо, варит его; затем, расстелив шкуру на земле, садится на нее, заложив обе руки за спину, как если бы они были связаны в локтях. Этим выражается у нас (т. е. скифов. - Ю. П.) самая сильная мольба. Когда мясо быка разложено, родственники и просто желающие подходят и берут каждый по куску. При этом они ставят правую ногу на шкуру и обещают доставить, кто сколько в силах. [...] Собирается таким путем на шкуре иногда большое число воинов. Такое войско самым стойким образом остается в строю и непобедимо для врагов, будучи связано клятвой: поставить ногу на шкуру является у нас клятвой» 6 .

Обращает на себя внимание, что в обоих обрядах - белорусском и скифском - присутствующие ставят правую ногу на сакральный предмет тотемического толка, с которым будто сливается центральный персонаж - «жених» ${ }^{7}$, и что оба обряда предшествуют свадебному набегу - очевидно, одной из наидревнейших и давно устаревшей к XIX в. форме заключения брака (добывания невесты) ${ }^{8}$. В то же время, оставаясь браком, утверждающим власть мужчины над женщиной, по тра-

\footnotetext{
${ }^{5}$ Там же. - С. 65.

6 Лукиан. Собрание сочинений. - М.-Л., 1935. - Т. 1. - С. 316.

${ }^{7}$ Подробнее о семантике этого обряда: Писаренко Ю.Г. До питання про українську ментальність та їі витоки // Проблеми теорії ментальності. - К., 2006. C. 315-317.

${ }^{8}$ Пономаръов А. Українська етнографія. Курс лекцій. - К., 1994. - С. 234.
} 
диции он сохраняет и наиболее знаковые моменты обряда бракосочетания, восходящие к эпохе становления патриархального брака - эпохе военной демократии. Интересны и другие моменты передачи этой традиции. Это и то, что относясь к скифскому быту VII-III вв. до н. э., эти подробности дошли до времени Лукиана - II-го в. н. э., а главное то, что традиция исчезнувших скифов всплывает у белорусов, среди предков которых были балты и славяне ${ }^{9}$.

Традиция, как внушаемая обществом каждому своему члену необходимость следовать определенным правилам, могла бы восприниматься как смиряющая «Я» человека. И это наиболее свойственно первобытному обществу, для которого подавление зоологического индивидуализма было вопросом выживания ${ }^{10}$. Тем не менее, современного человека мы также не можем представить себе вне связи с какимилибо общественными традициями. Как существо социальное, он обладает не только активной памятью, но и, так сказать, пассивной, в виде навыков, связанных с традициями воспитания. То есть, идентичность современного человека, его «Я» также зиждется на традициях.

В архаике традиция играет роль границы между «своим», принадлежащим своему упорядоченному обществу, и «чужим»-якобы асоциальным и деструктивным. Это хорошо заметно в приведенном нами свадебном обряде, представляющем собой консолидацию «своего», родового перед столкновением с чуждым, опасным. О том, что традиция подобна охранительному «магическому кругу», оберегающему некую территорию, говорит, например, следующий сюжет. Заметка Х. Л. Борхеса «Стена и книги» рассказывает о том, как в Китае (в конце III в. до н.э.) Первый Император Ши Хуан-ди, распорядившийся возвести Великую Китайскую стену, в то же время приказал сжечь все книги прежних времен, как полагают, для того, чтобы уничтожить историческую память. Очевидно, назвав себя «Первым», император стремился начать историю с себя, воссоздать начало времен ${ }^{11}$. Примечательно, что, закладывая новую традицию, Ши Хуан-ди одновременно физически ограничивал стеной территорию. Традиции намечено было пропитать собой это ограниченное пространство. Как ни вспомнить здесь современную метафору «железного занавеса» или реальную «Берлинскую стену» ${ }^{12}$.

\footnotetext{
${ }^{9}$ Мядзъведеў A. Насельніцтва Беларусі ў жалезным веку // Беларускі гістарычны агляд. - Мн., 1994. - Т. 1. - Сш. 1. - С. 37.

${ }^{10}$ Семенов Ю. И. Как возникло человечество. - М., 1966. - С. 242-251.

${ }^{11}$ Борхес Х. Л. Письмена Бога. - М., 1992. - С. 228-230.

${ }^{12} \mathrm{~B}$ то же время, связанный с Горбачевской Перестройкой, а по существу лом-
} 
С локальностью первобытной группы, территориально отделенной от других, связано и становление языка - средства передачи любой традиции и ее «плоти». Да и передача основ речи от поколения к поколению едва ли не главная культурная традиция.

Если межэтнические контакты с неизбежностью порождают письменность, то традиционная культура изолированной группы обычно связана с устными преданиями, опирающимися на характерные приметы населенного этой группой ландшафта ${ }^{13}$. Так, по словам С. А. Токарева, «для австралийца земля его общины вся насыщена религиозномагическими воспоминаниями: каждая скала, ущелье, водоем, дерево - все это есть либо место действия того или иного мифологического эпизода, либо метка, оставшаяся на память о таком эпизоде» ${ }^{14}$. Благодаря опоре на приметы местности, традиция выступает, скорее, не проявлением памяти, а, как бы, живой средой обитания. Здесь традиция не просто передается от поколения к поколению, а будто служит «крещальной купелью», в которую окунается каждый вновь пришедший в этот мир ${ }^{15}$. В результате, как писала О. М. Фрейденберг, «миф компонует одного члена семьи по чертам другого, и потомок всегда повторяет предка. [...] Такая горизонтальность мысли присуща архаике, как метод: это сказывается и в стабильности имен, и в переходящей от отца к сыну профессии или классовой принадлежности, и во всем том, что мы совершенно обратно воспринимаем, как «преемственность» и «традицию» ${ }^{16}$. То есть воспринимаемое нами, как сверху навязанная традиция, для людей древности было чем то более органичным, естественным. Здесь хотелось бы подчеркнуть не столько аспект передачи традиции новому поколению- от учителя к ученику, сколько объединения ею людей, одновременно живущих в коллективе. Возможно, принцип традиции был аналогичен ранее указанному нами архаичному восприятию зрения, как общего, единого для всего «рода» ${ }^{17}$, когда,

кой стен и традиций, пример показывает, насколько опасен для неподготовленного общества необдуманный отказ сразу от всех основополагающих принципов. В том же Китае это сумел предвидеть Ден-Сяопин, когда не стал развенчивать культ своего личного гонителя Мао после его смерти в 1976 г., а наоборот еще больше его усилил (Попович М. В. Червоне століття. - К., 2005. - С. 702).

13 Лотман Ю. М. Несколько мыслей о типологии культур // Языки культуры и проблемы переводимости. - М., 1987. - С. 8-11.

${ }^{14}$ Токарев С. А. Ранние формы религии. - М., 1990.-С. 72.

15 Зесь правильнее говорить не о «передаче», а о «вовлечении» в традицию.

${ }^{16}$ Фрейденберг О. Thamiris // Яфетический сборник.- Л., 1927. - Т. V. - С. 74.

${ }^{17}$ Писаренко Ю. Г. Зрение и слепота как социальные символы // Соціум. Альманах соціальної історії. - К., 2010. - Вип. 9. - С. 294-298 и далее. 
к тому же, все члены первобытного коллектива «имели совершенно одинаковое представление о том, что видели» ${ }^{18}$. Нечто от понимания традиции угадывается в образе невыговоренной, надъязыковой связи, упоминаемой О. Шпенглером: «Самым чистым символом согласия, которое преодолело язык, является старая крестьянская супружеская чета, которая сидит вечером у своего дома и молча беседует. Один знает, что думает и чувствует другой. Слова только нарушают это единство» ${ }^{19}$. Согласие - «совет да любовь», взаимная привязанность - необходимые составляющие традиции. Что либо способно утвердиться, укорениться на земле, только в любящем диалоге став традицией. Возможно, с этим же связана и известная парность образов святых ${ }^{20}$.

Образное понятие «лоно традиции» говорит и о том, что традиция призвана защитить от опасного «чужого», но и о любящем диалоге этого материнского начала с пестуемым дитятей. По существу, в приверженности человека традиции можно увидеть подсознательное стремление вернуться в оберегающее материнское лоно. Анализируя противостояние категорий зависимости и свободы, тот же О. Шпенглер первую связывает с укорененностью растения, а вторую с животным состоянием: «Стадо, трусливо сбивающееся в кучу в случае опасности, плачущий ребенок, прильнувший к матери, отчаявшийся человек, пытающийся найти утешение в Боге и слиться с ним, - все они хотят выйти из свободного существования и вернуться в зависимое, растительное, покинув которое они стали одинокими» ${ }^{21}$. Согласно ученому, в полной мере «растением» становится крестьянин, называющий землю «матушкой» 22 . Очевидно, термин «лоно традиции» как раз ука-

18 Фрейденберг О.М. Введение в теорию античного фольклора // Фрейденберг О. М. Миф и литература древности. - М., 1998. - С. 26.

${ }^{19}$ Шnенглер О. Закат Европы: Очерки морфологии мировой истории. - Мн., 1999. - Т. 2. - С. 173. Недаром говорят, что любящие и долго прожившие вместе супруги даже внешне становятся похожими друг на друга.

20 Толочко О. Смерть митрополита Константина (До розуміння давньоруської моделі святості) // Mediaevalia Ukrainica: Ментальність та історія ідей. - K., 1993.T. II. - C. 45-46.

${ }^{21}$ Шпенглер О. Указ. соч. - С. 7.

22 Там же. - С. 112. Тем не менее, можно говорить еще о доземледельческом почитании земли в качестве матери. Например, об этом красноречиво свидетельствует рассказ В.Г. Короленко «Марусина заимка». Здесь повествуется, как в XIX в. в Якутии местное скотоводческое население не только осуждает русского крестьянина-поселенца за распашку земли - живого существа, но и ночью, травой к верху, поворачивает весь нарушенный пахотой дерн. Примечательно, что главной на местной сходке выступает вдова родовича богатыря, тойонша, что, к тому же, указывает на связь между почитанием земли и женщины (Короленко В.Г. Собр. сочинений в 10-ти т. - М., 1953. - Т. 1. - С. 334-337). 
зывает на эту первичную материнско-детскую связь как модель традиции. С другой стороны, именно связь матери и ребенка, признаваемая исторически первичной ячейкой социальности ${ }^{23}$, может считаться истоком всей традиционности. В древних родовых, еще доземледельческих, представлениях «мать», «род» и «место-земля» сливались $^{24}$. «Мать представлялась „связью всего“, „причиной“ и ,местом“ бытия» ${ }^{25}$. У многих народов умирающих клали на землю, в убеждении, что душа как раз там, где положен умирающий, возвратится в материнское земляное лоно, точно также обратный переход к новорожденному души умершего предка, - чаще всего деда, из-под земли представляли себе возможным опять-таки только там, где состоялись роды $^{26}$. Но и сам жизненный путь отдельного человека был отмечен целой чередой переходных обрядов (rites de passage), символизировавших новое рождение после временной смерти - как бы, возвращение к истоку, в материнское лоно-землю, к началу времен. Автор учения о «переходном обряде» А. ван Геннеп выделял такие вехи жизни, отмеченные переходными обрядами, как рождение, достижение социальной зрелости, брак, беременность, отцовство, повышение общественного положения, профессиональная специализация, смерть. Кроме этого он указывал на переходные моменты в жизни Вселенной, также сопровождавшиеся переходными обрядами. К их числу он относил переход от одного месяца к другому, от одного времени года к другому, встречу Нового года и т. д. ${ }^{27}$. Те или иные традиции древности чаще всего были связаны с такими пограничными ситуациями в объединенной жизни социума и природы, и проявлялись в праздниках, ритуалах, во время которых будто бы заново создавался космос ${ }^{28}$.

${ }^{23}$ Соловъев Вл. Оправдание добра. Нравственная философия // Соловьев Вл. Сочинения в 2 т. - М., 1988. - Т.1.-С.128; Флюер-Лоббан ЖК. Проблема матрилинейности в доклассовом и раннеклассовом обществе // Советская этнография. M., 1990. - № 1. - C. 76 .

${ }^{24}$ Петров В. Опыт стадиального анализа «охотничьих игрищ» (к постановке вопроса) // Советская этнография. - М.-Л., 1934. - №6. - С. 150-151.

${ }^{25}$ там же. - C. 150.

${ }^{26}$ Комарович В. Л. Культ рода и земли в княжеской среде XI-XIII вв. // Труды Отдела древнерусской литературы Института русской литературы (Пушкинского дома) АН СССР (Далее- ТОДРЛ). - М.-Л., 1960. - Т. 16. - С. 104.

${ }^{27}$ Генеп А., ван. Обряды перехода. - М., 2002. - С. 9 и др.; Тэрнер В. Ритуальный процесс. Структура и антиструктура // Тэрнер В. Символ и ритуал. - М., $1983-$ С. 168 и далее.

28 Элиаде М. Миф о вечном возвращении. - М., 2000.-C. 57 и др.; Топоров В. Н. Первобытные представления о мире (общий взгляд) // Очерки естественнонаучных знаний в древности. - М., 1982. - С. 17-18. 
Универсальной моделью переходного обряда могла бы считаться так называемая клятва с дерном на голове, которая, кроме того, с нашей точки зрения, идеально передает смысл самого понятия «традиция». Впервые упоминаемая в славянском переводе Слов Григория Богослова («Слово об избиении градом») XI в., она вплоть до XIX в. использовалась в спорах русских крестьян о меже покосов. Обычно, крестьянин, доказывая принадлежность спорного участка сеножати, возлагал на голову кусок дерна с травой и клялся (иногда обходя межу), что если спорный участок не принадлежит ему, то покарает его мать-сыра земля ${ }^{29}$. Хотя по внешнему виду клятвы обычно считается, что прибегали к ней исключительно в спорах о земле, думаем, первоначально она была клятвой вообще, обозначая равноправный статус клянущегося - его принадлежность роду-земле - путем временной «смерти-погребения» под дерном. Отсутствие изначальной связи с земельными спорами подтверждает, например, принципиально сходный с этой клятвой обряд заключения договора у лютичей, приведенный Титмаром Мерзебургским в его «Хронике» (XI в.): обрезалась верхушка волос, смешивалась с травой и передавалась во время рукобитья ${ }^{30}$. По древним представлениям, правота человека доказывалась не столько обстоятельтвами дела, сколько его достойным происхождением $^{31}$, прежде всего, подтвержденной связью со «своим» родом-территорией. В частности, равноправие членов княжеского рода Рюриковичей выражалось его «причастием» (совладением) в «Русской земле» ${ }^{32}$. Подтверждая генетическое единство клянущегося лица с родом, клятва с дерном воспроизводила его возвращение в лоно рода-Матери земли и повторное рождение. В сущности, это действо может восприниматься в качестве «динамической модели» понятия традиции.

На примере приведенного обряда клятвы с дерном можем видеть, как традиция, вследствие экономических и социальных новаций, наполнялась новым смыслом и постепенно теряла прежний вес. Так, из модели родовой инициации она превращается в клятву ради обладания

${ }^{29}$ Павлов-Сильванский Н. П. Символизм в древнем русском праве // ПавловСильванский Н. П. Феодализм в России. - М., 1988. - С. 485-492; Писаренко Ю. Г. Велес-Волос в язичницькому світогляді Давньої Русі. - К., 1997. - С. 77-90.

${ }^{30}$ Котляревский A. А. Славянские древности. - Древности юридического быта балтийских славян. Опыт сравнительного изучения славянского права // Сборник Отделения русского языка и словесности Имп. АН. - СПб., 1895. - Т. 1. - С. 198.

${ }^{31}$ Гуревич А.Я. Проблемы генезиса феодализма в Западной Европе.-М., 1970. - C. 108-109.

${ }^{32}$ Комарович В.Л. Указ. соч.-С. 103; Толочко А.П. Князь в Древней Руси: власть, собственность, идеология. - К., 1992. - С. 25. 
землей, в то время, как ранее скорее доказывала принадлежность земле(роду) самого человека. В первой четверти XVIII в. И. Т. Посошков так писал о клятве с дерном: «Инии, забыв страх божий, взяв в руки святую икону, а на голову свою положа дернину, да отъводят землю и в таковом отъводе смертне хрешат. И много и того случаетца, еже отъводя землю и неправедную межу полагая, и умирали на меже» ${ }^{33}$. С одной стороны, традиционный обряд обхода межи с дерном автор называет грехом, в силу его языческой пережиточности и греховности клятвы вообще ${ }^{34}$. С другой, - знает о случаях, когда обманщик, заведомо пролагая неверную межу, на ней умирал, что, скорее всего, говорит о силе самовнушения, ибо человек в глубине души продолжал верить в Мать-землю, как справедливого и грозного судью. В связи с этим вспоминаем о разобранной М. Моссом теме воздействия на индивида коллективно внушаемой мысли о смерти, неизбежно наступающей в случае нарушения табу ${ }^{35}$.

Уже несколько другую ситуацию встречаем в статье Г. Соколова «Судья-земля» (1878 г.), где описывается обычай клятвы с дерном в Каргопольском уезде Олонецкой губернии. Здесь, в частности, говорится, что к спору, в конце концов разрешаемому обходом с дерном на голове, прибегают «хозяева двух смежных пожен, забыв граничную черту, или просто в видах захвата части чужого сенокоса» ${ }^{36}$, то есть, как и в прежнем примере, возможны варианты. Далее: «Если при этом несущий на голове землю, при обходе граничной межи и захватит край пожни соседа, с которым ведет спор, последний не обижается и добровольно отдает своему противнику всю обойденную им землю, приговаривая только, крестясь: „С Богом! Бери, что обошел: так рассудила нас мать сыра земля!"” ${ }^{37}$. Если над вторым крестьянином еще довлеет чистая вера в когда-то общую, родовую Мать-землю, то первый уже вполне способен пережить обман. И в этом случае, прибегая к традиционной клятве землей формально, в душе он уже изменяет

\footnotetext{
${ }^{33}$ Посошков И. Т. Книга о скудости и богатстве. - М., 1937. - С. 261-262.

${ }^{34} C \mathcal{M}$., напр.: «Благосостоятелен же и велидушен муж усрамится словеса верная клятвою изъявляти и своими нравы веру обесчещати.» (Послание константинопольского патриарха Фотия князю Михаилу Болгарскому в списках XVI в. (Публикация Н.В. Синицыной) // ТОДРЛ. - М.-Л., 1965. - Т. 21. - С. 119.

${ }_{35}$ Мосс M. Физическое воздействие на индивида коллективно внушенной мысли о смерти // Мосс М. Общества, обмен, личность.-М., 1996. - С. 230 и далее.

${ }^{36}$ Соколов Г. Судья-земля. Обычай, существующий в Каргопольском уезде Олонецкой губернии // Записки Имп. Русского геогр. Общества по отд. этнографии. СПб., 1878. - Т. VIII. - С. 17.

${ }^{37}$ там же. - С. 18.
} 
традиции, согласно которой мера «причастия» в роде-земле определяется, освящается самой землей. Традиция в этом примере проявляется для нас как основа совести, и даже, пожалуй, можно говорить о тождестве этих понятий. Во всяком случае, о совести М. Горький писал следующее: «в слове „совесть“ весть - производное от старославянского глагола „ведать“, знать. Понятие со-весть образовалось, наверное, по тому же закону, который действовал при образовании понятия сожитие, со-единение, со-гласие. Таким образом, первоначально понятием совесть обозначалось совместно всем родом выработанное, принятое и утвержденное как правда - знание - ведение о чем-либо социально полезном, что скрепляло взаимоотношения рода» ${ }^{38}$. Традиция как совместное знание, ведение заключает в себе триединую идею: она отмежовывает коллектив от «внешнего», сплачивает этот коллектив (причем, не отделяя живых от мертвых) и ставит каждого отдельного его члена на подобающее ему место ${ }^{39}$.

Образом этого триединства традиции мог бы считаться индоиранский бог Митра, с именем которого обычно связывают русское «мир» в значениях мирного существования, общины и космоса ${ }^{40}$. В Авесте Митра назван «выпрямителем линий (границ)», что указывает на его роль в пограничных спорах ${ }^{41}$. В Ригведе говорится, что «Митра объединяет (соединяет) людей», то есть помещает их в определенную социальную структуру $^{42}$. При этом слово «объединять», «организовывать» (людей $)^{43}$ может поясняться и как «занять собственное место, свое естественное положение по отношению к другим» ${ }^{44}$. Приводить людей к союзу и ставить их на истинное место в отношениях с другими, по мне-

\footnotetext{
${ }^{38}$ Горъкий М. Собрание сочинений в 30-ти т. - М., 1953. - Т. 24. - С. 557. Аналогично о совести: Фрейд З. Тотем и табу // Фрейд 3. «Я» и «Нно. Труды разных лет. - Тбилиси, 1991. - Кн. 1. - С. 261.

${ }^{39}$ Особое внимание идее «подобающего места» уделяет культура Японии (Бенедикт P. Хризантема и меч: модели японской культуры. - СПб., 2007).

${ }^{40}$ Кошеленко Г.А. Ранние этапы развития культа Мифры // Древний Восток и античный мир / Сб. статей, посв. В.И. Авдиеву. - М., 1972. - С. 78; СрезневскийИ.И. Словарь древнерусского языка.-М., 1989.- Т. 2.- Ч. 1. Стб. 147-151.

41 Топоров В. Н. Митра // Мифы народов мира. Энциклопедия.-М., 1988.T. 2. - C. 155 .

42 Топоров В.Н. Об иранском элементе в русской духовной культуре // Славянский и балканский фольклор. - М., 1989. - С.44.

43 Ригведа. Мандалы I-IV / Изд. подг. Т. Я. Елизаренкова. - М., 1989. - С. 719.

44 Дюмезиль Ж. Верховные боги индоевропейцев / Пер. с франц. Т. В. Цивьян. М., 1986. - С. 213. - Прим. 24.
} 
нию Ж. Дюмезиля, значения весьма близкие ${ }^{45}$. Кроме того, с точки зрения подобия между Митрой и традицией в ее архаическом понимании, важна и посредническая функция Митры не только в отношении один к другому людей, но и в их отношении к богам ${ }^{46}$. Сама связь Митры с мерой и обменом (ср. и.-евр. ${ }^{*} m \bar{e}-$ мерить, ${ }^{*} m e i-$ менять $)^{47}$ роднит его с представлением о традиции. Тот или иной традиционный ритуал обычно предполагает повторяемость, диктуемую космическими и жизненными ритмами, и служит приведением в порядок, уравновешиванием, переходом от космоса к хаосу и обратно, уходом в «материнское лоно» и возвращением на белый свет.

Традиция с заложенным в нее принципом «меры», подобным Гераклитовскому огню, созвучна также образу Софии-Премудрости. Греческие и библейские представления о Мудрости говорят о ней, как о мере, законе и равновесии, лежащем в основе дома, города, мироздания. Как и традиция, она несет в себе идею общности, сплочения, соборности ${ }^{48}$. Женский облик Софии, близкой мифологическому и фольклорному образу мудрой девы ${ }^{49}$, восходит к слитному представлению о женщине-роде-территории, о родительнице, как основе передачи традиций. Одним из олицетворений этой первобытной мудрости была мать-турица в ранее рассмотренной нами былине ${ }^{50}$. В какой-то степени ей близка «полумедведица» Артемида, обладавшая разграничительной функцией «своего» и «чужого», прививавшая традиции молодежи и со временем ставшая покровительницей городов ${ }^{51}$. Все архаические образы девственно-материнских хранительниц традиций ведут к родовой, еще доземледельческой Матери-земле, влияние

45 там же. - C. 47.

46 Топоров В. Н. Об иранском элементе...-С. 59. - Прим. 70.

47 Там же. - С. 59-60.

${ }^{48}$ Аверинцев C. C. К уяснению смысла надписи над конхой центральной апсиды Софии Киевской // Древнерусское искусство. Художественная культура домонгольской Руси. - М., 1972. - С. 30-35.

${ }^{49}$ Там же.-С. 28; Аверинцев С. С. К истолкованию символики мифа о Эдипе // Античность и современность. - М., 1972. - С. 96-97.

${ }^{50}$ Писаренко Ю. Г. Соціальна стратиграфія архаїчного образу (на прикладі билини про турів) // Актуальні проблеми духовності. Зб. наук. праць / Ред. Я. В. Шрамко. - Кривий Ріг, 2011. - Вип. 12. - С. 263, 271-272 і далі.

${ }^{51}$ Вернан Ж.-П. Смерть в очах. Втілення потойбічного світу в античній Греції: Артеміда, Горгона.-К., 1993. - С. 13, 14, 17, 20, 22, 24. Яркой иллюстрацией трансформации хтонической матери всего живого в защитницу городов является скульптура Артемиды (Дианы) Эфесской III-II вв. до н. э. в виде многогрудой женщины, одежда которой густо покрыта изображениями разных животных, а голова украшена городской башней (Тахо-Годи А.А. Артемида // Мифы народов мира. Энциклопедия. - М., 1987. - Т. 1. - С. 108. - Рис.). 
которой обнаруживается как в Софии ${ }^{52}$, так и в Деве Марии ${ }^{53}$. Мать, род-земля, традиция и Премудрость - «материнское лоно изначальности», первопринцип бытия ${ }^{54}$ - все это опорные представления в жизни человечества, дающие ему чувство защищенности ${ }^{55}$.

Памятуя об особой связи Софии с Киевом, напомним о значении собственно «киевской традиции» не только для Украины и Руси в широком смысле слова, но и для мировой духовности в целом ${ }^{56}$. Вложенные летописцем в уста князя Олега слова: «Се буди мати градомъ русьскимъ» ${ }^{57}$ отражают представление о городе, как о «женщине»наследнице образа Матери-земли ${ }^{58}$, а также об особом, «материнском» статусе Киева по отношению к другим русским городам (перевод греческого «митрополис»). Автор «Повести временных лет», работавший в начале XII в. в Киеве, освященном к тому времени образом Софии, стремился показать, что на территории столицы Премудрость имела исконные основания. О первых насельниках киевских гор он пишет: «бяху мужи мудри и смыслени, нарицахуся поляне» ${ }^{59}$. Со времен княжеских междоусобиц и татаро-монгольского нашествия 1240 г. Киев не раз подвергался жестоким испытаниям. Но символом его стойкости оставалось мозаичное изображение Богоматери в храме Софии, получившее название «Нерушимой Стены» ${ }^{60}$. В этом образе воедино сплелись мудрость Киевской духовной традиции и, вопреки всему, сохранность неповторимого архитектурного облика Киева.

Однако, в наше время, казалось бы, в условиях мира, Киев и киевская духовность, духовность нашего народа в целом переживают не-

${ }^{52}$ Шепфлингер Т. София-Мария. Целостный образ творения. - М., 1997. C. 216, 221.

${ }^{53}$ Белецкий A.A. Греческие надписи на мозаиках Софии Киевской // Лазарев В. Н. Мозаики Софии Киевской. - М., 1960. - С. 30.

${ }^{54}$ Аверинцев C. С. К уяснению смысла надписи. .- - С. 34.

${ }^{55}$ Ср.: Баронин А. С. Этническая психология.-К., 2000.- С. 53: «Придерживаясь традиций той или иной социальной среды, человек выражает свою солидарность и принадлежность к ней, за что получает одобрение и поддержку - источник позитивно окрашенного эмоционального состояния, которое можно назвать «чувством защищенности», и в результате-внутренний душевный комфорт».

${ }^{56}$ По словам С.Б. Крымского, «Киев можно рассматривать не только как славянскую столицу, но и как семиотическую систему, либо текст, который кодирует языком материально-пространственной среды представление о разумной ойкумене» (Кримсъкий C. Софійні символи буття // Кримський С. Б. Запити філософських смислів. - К., 2003. - С. 65).

${ }^{57}$ Повесть временных лет. - М.-Л., 1950. - Ч. 1. - С. 20.

${ }^{58}$ Писаренко Ю. Г. Соціальна стратиграфія архаїчного образу. . - С. 257-258.

59 Повесть временных лет. - С. 13.

60 Закревский Н. Описание Киева. - М., 1868. - Т. 2. - С. 791. 
виданное испытание. Из недр, вроде бы, «своей» традиции показался «чужак», для которого понятие совести как совместного знания утрачено и ему можно уже не стыдиться «клясться иконой и дерном в виду захвата чужой земли». С киевских улиц один за другим исчезают памятники старинной архитектуры, а новые «шедевры» стремятся затмить саму Софию. Поистине знаковым ударом по традиционной культурной среде Киева стало фактическое уничтожение в 2003 г. Музея истории Киева, выселенного из старинного Кловского дворца, ради передачи последнего под помещение Верховного суда ${ }^{61}$. Изгнание судом музея весьма символично, ведь, как справедливо заметил киевовед В. Ковалинский: «Связь в обществе прямая - чем меньше музеев, тем больше нужно судей» ${ }^{2}$. Молодежь видит вокруг и воспринимает пренебрежение не только к традициям культуры, но и - самой человечности. Если за акцию приготовления на Вечном огне яичницы можно получить хотя бы формальное осуждение, то ежедневно колесить на роликовых досках над массовым погребением арсенальцев в парке у здания Верховного совета разрешается целиком безнаказанно.

Есть нечто парадоксальное в том, что, по мере возрождения прежде разрушенных и возведения новых храмов (даже связанных с памятью о Голоде 1930-х), духовная и душевная традиция Киева исчезает. Поскольку «любить себя в Киеве» становится невозможным, только и остается, что «любить Киев в себе»... Вспоминается легендарный Китеж-град, с церквями, домами и людьми ушедший под землю и живущий в параллельном, духовном мире, очевидно, лишь в силу памяти о нем живущих. Последний огонек традиции, ранее оберегавшей нас как материнское лоно, теперь теплится в нас самих, и остается только верить, что найдется тот, у кого будет потребность его от нас принять.

Надійшла до редакчіӥ ч квітня 2012 р.

${ }^{61}$ Ковалинсъкий В. Київські мініатюри. - К., 2006. - Кн. 1. - С. 110-115.

62 Там же. - С. 108. 